\title{
Evaluating Instructional Effects of Flipped Classroom in Higher Vocational Colleges: A Case Study on Marketing Practice Course
}

\author{
Liang Yanbing
}

\begin{abstract}
The main purpose of this study is to explore the instructional effects of flipped classroom in marketing practice course in higher vocational education, and to confirm instructional effects by teaching experimental research. The participants of the study are students majoring in marketing. Students in the experimental group received flipped classroom teaching, and the control group received the traditional teaching method. This research evaluates instructional effects by using the students' learning achievements, learning interests and course satisfaction. The research results show that flipped classroom can effectively improve the students' learning achievement, encourage more students to actively participate in active learning, improve students' satisfaction of course, obtaining good results in the practical teaching, but no significant advantage to improve the students' interest in learning.
\end{abstract}

Index Terms-Flipped classroom, pedagogical mode, marketing practice course, instructional effects.

\section{INTRODUCTION}

Flipped classroom, as a new pedagogical mode based on information technology, has become a hot topic of global education, and was voted the globe and mail of Canada in 2011 affect the classroom teaching of major technological changes (Milman, 2012) [1]. In recent years, flipped classroom has become popular at home and abroad, and many schools have devoted themselves to the reform of flipped classroom. Flipped classroom is to turn the traditional teaching structure. The teachers provide learning resources for students which students completed before class. Teachers and students in the class together to complete the practical tasks, and after class to carry out collaborative exploration and other activities.

\section{LITERATURE REVIEW}

\section{A. Background of Flipped Classroom}

Flipped classroom, which originated in the "woodland park" high school in Rockies, Colorado, USA. Many scholars in European and American countries have carried out in-depth studies on flipped classroom, such as Jon Bergmann and Aaron Sams (2012) [2]. Dr Freeman of the University of Washington (2013), conducted an empirical study to find that the percentage of students who fail to pass the curriculum has

Manuscript September 15, 2018; revised January 24, 2019.

Liang Yanbing is with Guangdong Vocational College of Posts and Telecom, China (e-mail: 364173092@qq.com). fallen from 17 per cent to 4 per cent [3]. Scholars from Stanford university, Massachusetts institute of technology and British Columbia University have also conducted empirical studies on flipped classroom (Deslauriers et al., 2011) [4], and achieved better teaching results than expected. In recent years, the teaching practice of "flipped classroom" has been quietly developed in the field of education in China. Yueguo Zhang and Yujiang Zhang (2012) [5], Jinlei Zhang, Ying Wang and Baohui Zhang (2012) [6], Xinglong Zhao (2013) [7], Quanlei Zhang \& Baohui Zhang (2013) [8], Shusheng Shen et al., 2013) [9] have systematically introduced and analyzed the flipped classroom. However, there are relatively few practical and empirical studies on flipped classroom in China, which mainly focus on engineering and basic subjects, and empirical research in the field of business is very scarce. Yan Jin (2014) [10] and Chunxia Lan (2015) [11] found that in computer foundation course, flipped classroom has a certain positive effect on improving students' self-learning habit and ability. Scholars from Nanjing University of aeronautics and astronautics carried out the "flipped classroom" by teaching 216 nonEnglish majors students, and gained the recognition of students. Scholar from South China normal university has tried to adopt flipped classroom in education technical English courses (Ling Li, 2015) [12]. Flipped classroom being developed from the practice of a few scholars into an innovative teaching theory, should have strong guidance mode of instructional design, combining with the course and obtain a better instructional effects [13].

\section{B. Basic Processes of Flipped Classroom}

Based on the case study of flipped classroom by domestic and foreign scholars, the author summarized the four basic processes of flipped teaching:

Problem guide: the teacher selects video and network document information carefully before class, and provide these learning resources to students.

Pre-class study session: the students download the learning materials before class, complete the exercises assigned by the teacher, and give feedback to the teachers in various ways (P. Schmidt et al., 2016) [14].

In the interactive links: the teacher collects problems that the students did not understand, then communicates with students in class and interacts in class to solve these problems, and encourages the group to actively participate in the solution through debates, simulated experiences and competitions.

Sublimation process after class: complete teaching effect feedback and evaluation. Students apply their knowledge and 
skills to practice and broaden their horizons.

\section{Characteristics of Flipped Classroom}

Transfer of teaching process. Flip upside down the traditional teaching process. Students should complete their own independent study of the course content before class. In the classroom, teachers and students will interact and practice tasks, and put the process of knowledge internalization into the course to maximize the teaching benefits.

Change of roles of teachers and students. In traditional teaching, teachers impart knowledge, while students usually passively accept knowledge. In flipped Classroom, the role of the teacher has changed to "director" and "coach", while the students are transformed into active participants in the teaching activities. The interaction between teachers and students is higher (Demski, 2013) [15].

Diversified learning styles. With the continuous innovation and popularization of teaching media and learning tools, the new teaching mode has overturned the traditional teaching situation. The short and concise teaching video is the main method of knowledge transfer in flipped classroom. Through the short teaching video, the knowledge is decomposed into a number of small parts, and the key points are more prominent (Frydenberg, 2012) [16]. In addition, students' access to knowledge is more diversified, such as student management platform, mobile learning terminal, mobile phone, computer and so on. Through online and offline the reasonable use of teaching resources and integrate, students learn independently and form a more relaxed learning atmosphere, where students truly become masters of the classroom.

\section{Background of Marketing Practice Course in Higher Vocational Colleges}

The marketing practice course is a professional basic course for students of marketing in higher vocational colleges. This course mainly focuses on the marketing activities and regularity of the enterprises in the center of consumer demand, which lays a theoretical foundation for the study of the follow-up professional core courses. This course cultivates the senior application-oriented marketing management talents with professional marketing theory foundation and marketing practice application ability. On the one hand, it cultivates students interest in marketing, forming the correct market consciousness and the concept of marketing, and prompts students to understand the basic theory of marketing, basic knowledge and basic methods. On the other hand, it focuses on training students' practical skills and let them use marketing theory to discover, analyze and solve practical marketing problems.

However, there are some problems in the teaching of marketing practice course, specific as follows:

Firstly, at present, the students in higher vocational colleges have the problems such as weak learning ability, low enthusiasm for learning, and differences in students' abilities, which pose severe challenges to traditional teaching. Especially in the face of students with different students, traditional teaching cannot be unified in teaching progress and knowledge, and take care of all students' learning needs.

Secondly, marketing practice course is a practical application of curriculum, with large capacity and update fast content. With the advent of the "Internet +" era, many new marketing concepts and methods have emerged. Single classroom teaching in traditional teaching mode is difficult to keep up with the development and practice of the discipline. It cannot highlight the flexible and comprehensive features of the curriculum of higher vocational colleges, and meet the requirements of cultivating high-quality technical talents with theoretical knowledge and strong practical ability.

Thirdly, the key points of higher vocational courses are mainly determined by teachers before class. The students passively accept the difficult teaching of the curriculum whose learning initiative is not well developed, so the teaching results are not outstanding. Students do not know the content of the course before they study, and they will not actively follow the teacher's instruction in the course of the class. It is easy to make the course learning effect less obvious and the effect of classroom teaching is poor.

Based on flipped classroom is a kind of new teaching mode, which can realize the effective interaction between teachers and students, this paper in view of the actual situation of higher vocational marketing professional students, attempts to explore a set of flipped classroom design patterns suitable for application in higher vocational marketing practice course. By means of contrast experiment and the research methods of questionnaire survey, using the students learning achievement, learning interest, course satisfaction as indicators of the instructional effects, the author examines the effectiveness of the flipped classroom in order to provide reference for the pedagogical mode of marketing practice course in higher vocational education.

The research questions are as follows:

1) Is there any difference between the knowledge or skills of students generated by the flipped classroom and the traditional classroom?

2) Is there any difference between the students' interest in learning before and after the flipped classroom?

3) Is there any difference between the students' interest in learning before and after the traditional classroom?

4) Is there any difference between the students' satisfaction with the marketing practice course before and after the flipped classroom?

5) Is there any difference between the students' satisfaction with the marketing practice course before and after the traditional classroom?

\section{MATERIALS AND METHODS}

\section{A. Research Design}

The study participants were freshmen majoring in marketing at the school of economics and management of Guangdong Vocational College of Posts and Telecom. There were 110 students in 2 classes, including 52 in class A and 58 in class B. The students who participated in the experiment were divided into classes according to the principle of uniform distribution of college entrance examination results. All students took the same courses before participating in the study, and the learning ability started at the same level. 


\section{B. Course Contents}

This study selected "product strategy" section of marketing practice course as teaching content. Through the modularization design of the teaching content, the main products were hierarchical structure analysis, product portfolio strategy, product life cycle and brand strategy. These four modules were the focus of "marketing practice", which required students not only to master the concept and principle of theory, but also to grasp the application situation and method of theory in teaching. The two classes were taught by the same teacher, and the teaching activities were conducted in a total of 8 hours (including pre - and post-test and 4 teaching). Class A (experimental group) adopted the flipped teaching mode and class B (control group) adopted the traditional teaching mode. The study design was shown in Table I.

TABLE I: THE DESIGN OF THE EXPERIMENTAL CONTROL GROUP IN THIS

\begin{tabular}{|c|c|c|c|}
\hline \multicolumn{4}{|c|}{ STUDY } \\
\hline Pre-test & Group & Post-test & $\begin{array}{c}\text { Delays after } \\
\text { test } \\
\text { (six weeks later) }\end{array}$ \\
\hline \multirow{2}{*}{$\begin{array}{l}\text { Student } \\
\text { achievement } 1 \\
\text { Interest } \\
\text { in learning } \\
\text { Course } \\
\text { satisfaction }\end{array}$} & $\begin{array}{l}\text { Experimental } \\
\text { group (flipped } \\
\text { classroom) }\end{array}$ & \multirow{2}{*}{$\begin{array}{l}\text { Student } \\
\text { achievement } 2 \\
\text { knowledge, } \\
\text { skill } \\
\text { Interest } \\
\text { in learning } \\
\quad \text { Course } \\
\text { satisfaction }\end{array}$} & \multirow{2}{*}{$\begin{array}{c}\text { Student } \\
\text { achievement } 3 \\
\text { (knowledge) } \\
\text { Interest in } \\
\text { learning } \\
\text { Course } \\
\text { satisfaction }\end{array}$} \\
\hline & $\begin{array}{l}\text { Control group } \\
\text { (traditional } \\
\text { classroom) }\end{array}$ & & \\
\hline
\end{tabular}

\section{Course Activities}

According to the understanding of flipped classroom and the characteristics of higher vocational marketing teaching, based on the inherent characteristics of marketing course, the author put forward the teaching design model of "self-study before class, practice in class and sublimation after class". Through the integration of various teaching resources in the learning process, teachers provided services for students' independent study and collaborative learning in class. The experimental group adopted flipped classroom, and the specific teaching design was as follows:

\section{1) Self-study before class}

The teaching objective of this stage was to give students a preliminary understanding of the knowledge points. Specific implementation included three parts: first, students downloaded the video through the Internet and watched the teachers teaching electronic documentation, such as marketing teaching video, excellent marketing video lecture, quality teaching courseware, etc. The materials could help students quickly understand the contents of this module. In order to keep the students' attention, the length of micro video was not more than 10 minutes. Secondly, students completed the corresponding exercises on the network to enhance the understanding of video. At the same time, students could find problems in the learning process by doing exercises. Thirdly, students feedback the problems existing in this stage of learning through the Internet to the teachers. Teachers could prepare lessons pertinently.

\section{2) Practice in class}

"Internalization in class" was the key stage of successful implementation of "flipped classroom". In class, it was mainly used for the interaction between teachers and students, answering questions, internalizing knowledge, and reporting and discussing.

Knowledge of the feed/difficult feedback: in the first 10 to 20 minutes of the class, the teacher generalized, sorted out the knowledge frame, answered the student's questions, and helped the students to realize the overall grasp and integration of the knowledge.

The task of actual combat: the teachers set up tasks and competition rules according to the characteristics and teaching objectives of the teaching content in advance, such as "product hierarchy analysis drill". Students completed the task through the team cooperation and used what they had learned to solve problems.

Show results and exchange views: each group displayed their own works and shared their knowledge through the group, so that students could compete and learn from each other, and further optimize the task. The study adopted the method of teacher evaluation and student mutual assessment to carry out periodical assessment, so as to deepen the degree of knowledge internalization and improve students' interest in learning.

\section{3) Sublimation after class}

Students learned about product portfolio decision and life cycle theory and internalize in class before class. However, students still had a vague idea of how to apply this theory to the practice of Chinese enterprises. In order to guarantee the teaching effect, it was very important to consolidate and expand the knowledge after class. Therefore, teachers must provide development practice after class, such as study materials, reference books and related external links for students' autonomous learning. Students were required to explore derivative problems, self-reflection, migration and sublimation to form a deep memory trace and higher levels of cognitive processing.

\section{Data Analysis}

The collected data included pre-test, post-test, delays after test (six weeks later), student's midterm homework, the mid-term test, interest in learning, course satisfaction, flipped classroom learning experience questionnaire, after-class interview and so on.

1) The scale of students' interest in learning was based on the Taiwan PISA 2006 student questionnaire using Likert's four-point scale, which had good reliability and validity. The author revised it according to the situation of this course.

2) Knowledge testing included pre-test, post-test, delays after test. Among them, the pre-test adopted the students' admission scores. Post-test questionnaire was used to design the knowledge points of the teaching unit, and the questionnaire was combined with a total of 100 scores. The questionnaire of delayed knowledge was in the form of parallel questionnaire, which was consistent with the difficulty of the posttest questionnaire. The post-test student skills test was based on the actual combat 
situation of the students in the course.

3) The course satisfaction questionnaire adopted the Likert's five-point scale, which mainly evaluated the overall impression of the course and the teacher, the content of the course and the effect of teaching.

4) Flipped classroom experience questionnaire adopted the Likert's five-point scale, which mainly investigated the attitude, feelings and learning effects of flipped classroom, and also set open questions to collect students' opinions and suggestions on flipped classroom.

5) After-class interview. Six students (4 male and 2 female) were selected from the experimental group, mainly to measure their interest in the course, attitude to flipped classroom and traditional classroom, teaching opinions and Suggestions, etc.

\section{RESULTS}

\section{A. Quantitative Results}

\section{1) Differences in subject knowledge and skills}

Through the analysis of the students' admission scores in the experimental group and the control group, Independent sample t-test results shown that the control group averages of 305.14 points, the experimental group averages of 308.73 points. This indicated that there was no significant difference ( $t=0.204, p=0.838)$ in subject knowledge between the control group and the experimental group, which could meet the requirements of control experiment.
Through MyCOS research platform, the author carried out post-test of the experimental group and the control group to test students whether the knowledge and skills generated by students in flipped classroom were different from those generated in traditional classroom.

In regard to subject knowledge, as can be seen from Table II, the results of the experimental group were significantly higher than that of the control group. In regard to subject skills, there was no significant difference between the experimental group and the control group. In regard to subject knowledge of Delays after test (6 weeks later), the score of the experimental group was 55.77, higher than the control group 49.66, but not significantly different. This indicated that flipped classroom was beneficial for students to master the subject knowledge in a short time. By setting learning content, participatory interaction, flipped classroom can realize a perfect learning experience, with classroom inspiration sublimation could also help students better understand the subject concept. This conclusion was consistent with the research findings of Qi Zhang \& Lingyu Yang (2016) [17] in the course of modern education technology in university. In addition, the test results of the subject skills shown that the flipped classroom had no obvious advantage to the students' skills. This is because the student's skill needs to be in a certain situation, through the way of doing more exercises to be able to translate the knowledge into effective transformation.

TABLE II: INDEPENDENT SAMPLE T TEST BEFORE AND AFTER SUBJECT KNOWLEDGE AND SKILLS

\begin{tabular}{l|c|c|c|c|c|c}
\hline \multirow{2}{*}{ Achievements in knowledge and skills } & experimental group $(N=52)$ & \multicolumn{2}{|c|}{$\begin{array}{c}\text { control group } \\
(N=58)\end{array}$} & \multirow{2}{*}{$t$} & \multirow{2}{*}{$t$} \\
\cline { 2 - 6 } & $\mathrm{M}$ & $\mathrm{SD}$ & $\mathrm{M}$ & $\mathrm{SD}$ & & \\
\cline { 2 - 7 } Admission results & 308.73 & 91.527 & 305.14 & 92.550 & -0.204 & 0.838 \\
\hline Post-test Knowledge scores & 76.15 & 16.821 & 63.28 & 17.309 & -3.948 & $<0.0005$ \\
\hline Post-test skill scores & 85.73 & 6.791 & 86.74 & 5.489 & 0.009 & 0.993 \\
\hline Knowledge scores of delays after test & 55.77 & 23.544 & 49.66 & 23.167 & -1.371 & 0.173 \\
\hline
\end{tabular}

\section{2) Differences in interest in learning}

The paired sample t-test found that the students in the experimental group shown no significant differences in interest in learning before and after the flipped classroom. The students in the control group shown obvious differences in interest in learning before and after the traditional classroom. After the traditional classroom, the students' interest in learning was significantly improved. Some students in the experimental group and the control group were given the following reasons:

The students in the experimental group believed that although flipped classroom was better for interaction and communication, the classroom atmosphere was active, but it required extra time to study independently and increase the academic burden. At the same time, it was more difficult to control time and rhythm than traditional classroom. In addition, individual students became "free rider" when completing group tasks, which had a negative impact.

The students in the control group thought that through the traditional teaching of teachers, they were exposed to more and more interesting cases in the classroom. They liked the teaching styles and methods of teaching teachers, and they were happy to acquire new knowledge and gained a lot.

TABLE III: PAIRED SAMPLE T TEST OF INTEREST AND COURSE

\begin{tabular}{|c|c|c|c|c|c|c|}
\hline \multicolumn{7}{|c|}{ SATISFACTION IN CLASS } \\
\hline \multirow{4}{*}{$\begin{array}{l}\text { Interest in } \\
\text { learning }\end{array}$} & \multirow{2}{*}{ group } & \multicolumn{2}{|c|}{ Pre-test } & \multicolumn{2}{|c|}{ Post-test } & \multirow[b]{2}{*}{$\mathrm{p}$} \\
\hline & & $\mathrm{M}$ & SD & $\mathrm{M}$ & SD & \\
\hline & $\begin{array}{c}\text { experimental } \\
\text { group } \\
(\mathrm{N}=52)\end{array}$ & 16.25 & 2.248 & 16.12 & 2.272 & 0.746 \\
\hline & $\begin{array}{c}\text { control group } \\
(\mathrm{N}=58)\end{array}$ & 15.97 & 2.721 & 17.24 & 2.729 & 0.018 \\
\hline \multirow{2}{*}{$\begin{array}{c}\text { Course } \\
\text { satisfaction }\end{array}$} & $\begin{array}{c}\text { experimental } \\
\text { group } \\
(\mathrm{N}=52)\end{array}$ & 41.81 & 6.645 & 43.83 & 5.940 & 0.082 \\
\hline & $\begin{array}{c}\text { control group } \\
\qquad(\mathrm{N}=58)\end{array}$ & 44.79 & 4.923 & 41.76 & 5.939 & 0.003 \\
\hline
\end{tabular}

\section{3) Differences in course satisfaction}

From Table III paired sample t test, it could be seen that the students in the experimental group had a higher degree of 
satisfaction with the course after receiving the class, but the difference was not significant. The conclusion and the previous research to present certain distinction, research of Taiwan scholar Venxiong Dai, Yude Wang, Rui Wang, Jialing Chen (2016) had shown that flipped classroom could significantly enhance the students to the implementation of science and technology course satisfaction[18].

After receiving the traditional teaching, the students in the control group decreased their satisfaction with the course, presenting a significant difference $(p=0.003)$. According to the 10 questions of the students' satisfaction questionnaire in the control group, the sample $t$ test was conducted to find that after the students received the traditional teaching, satisfaction with the teacher $(p=0.007)$, arouse the enthusiasm for learning $(p=0.005)$, lead $(p=0.001)$ positive thinking, encourage participation discussion $(p=0.015)$, and the course challenging and thoughtful $(p=0.020)$ in terms of evaluation has dropped significantly; There was no significant difference between teachers' enthusiasm for teaching and learning valuable knowledge. This shown that flipped classroom had a good effect on improving students' participation and guiding positive thinking.

\section{4) The analysis of the flipped classroom learning experience questionnaire}

After the product strategy chapter flipped classroom implementation, the author conducted a "flipped classroom" marketing practice study experience questionnaire. The students' feedback were as follows (list some typical questions):

TABLE IV: THE RESULTS OF THE FLIPPED CLASSROOM LEARNING EXPERIENCE

\begin{tabular}{|c|c|c|c|c|c|}
\hline & strongly agree (\%) & agree $(\%)$ & general $(\%)$ & disagree $(\%)$ & $\begin{array}{l}\text { strongly } \\
\text { disagree }(\%)\end{array}$ \\
\hline $\begin{array}{l}\text { Like the course of marketing } \\
\text { practice }\end{array}$ & 46.15 & 36.54 & 17.31 & 0 & 0 \\
\hline Like flipped classroom & 46.15 & 38.46 & 13.46 & 1.92 & 0 \\
\hline $\begin{array}{l}\text { Flipping the classroom gives } \\
\text { you a better grasp of knowledge } \\
\text { and skills }\end{array}$ & 42.31 & 46.15 & 11.54 & 0 & 0 \\
\hline $\begin{array}{l}\text { Flipped classroom is more } \\
\text { interesting than traditional } \\
\text { classroom }\end{array}$ & 36.54 & 48.08 & 13.46 & 1.92 & 0 \\
\hline $\begin{array}{l}\text { Independent learning ability has } \\
\text { been improved }\end{array}$ & 34.62 & 42.31 & 19.23 & 3.85 & 0 \\
\hline $\begin{array}{l}\text { Flipped classroom allows you } \\
\text { and teachers to interact and } \\
\text { communicate better in class }\end{array}$ & 34.62 & 48.08 & 13.46 & 3.85 & 0 \\
\hline $\begin{array}{l}\text { Willing to continue to use } \\
\text { flipped classroom }\end{array}$ & 36.54 & 50.00 & 9.62 & 3.85 & 0 \\
\hline
\end{tabular}

As could be seen from Table IV, 82.69 percent of students enjoyed the course of marketing practice. 84.61 percent of students liked flipped classroom. 88.46 percent of students believed that flipped classroom enabled them to better master knowledge and skills. 84.62 percent of students thought that flipped classroom was more interesting than traditional classroom. 76.93 percent of students believed that self-learning ability was improved after flipped classroom. 82.7 percent of students believed that flipped classroom enabled them to interact and communicate better with teachers. 86.54 percent of students were willing to continue to use flipped classroom. It could be seen that flipped classroom had a positive effect on improving students' knowledge and skills, learning interest and independent learning ability, and enhancing interaction and communication with teachers.

\section{B. Qualitative Results}

In this study, six students (4 male, 2 female) in the experimental group were interviewed, including good performance/poor performance. The survey was mainly from the interest of course, attitude to flipped classroom and traditional classroom, teaching opinions and suggestions.

The interview found that students are more inclined to flipped classroom than traditional classroom. They believed that using flipped classroom will enable them to better master the subject knowledge and skills, as well as learn more extracurricular development knowledge. The atmosphere in the classroom was lively, and there was more interaction and communication, Flipped classroom could enhance both emotions and teamwork. Students' autonomous learning ability and participation were higher. However, with flipped classroom, teachers should better control the time and rhythm of the classroom, and adopt a way to avoid the "free rider" of group members. At the same time, teachers should spend a little more time to emphasize the key points and difficulties of the content and to supplement better cases when using the way students teach students.

\section{CONCLUSION}

Through the method of experimental research, this paper discussed the instructional effects of flipped classroom in marketing practice course in higher vocational education. Students in the experimental group received flipped classroom teaching, and the control group received the traditional teaching method. It had been proved in practice that flipped classroom could significantly improve students' academic achievement in a short time compared with traditional classroom. (Amstelveen \& Raoul, 2018; Song \& Kapur, 2017; Missildine et al., 2013;Kim et al., 2017; 
Aşıksoy \& Gülsüm, 2018) [19]-[23], but had no obvious effect on improving the discipline skills; flipped classroom helped to encourage more students to actively participate in active learning and more interactive communication in the classroom (Millard. E, 2012; Min-Kyung Lee, 2018; Boevé et al., 2017; Limniou et al., 2018) [24]-[27], and it could both improve the relationship, teamwork, and students' satisfaction with the course (McLean et al., 2016; Smith, 2017) [28], [29]. But flipped classroom had no obvious advantage in improving students' interest in learning.

In conclusion, we believe that compared with traditional teaching, flipped classroom is of great significance for reforming higher vocational teaching and improving teaching effect in many aspects, but it also puts forward new requirements for higher vocational teaching. After the reform and exploration of flipped classroom, the author believes that the key factors restricting the effective implementation of flipped classroom in higher vocational colleges are as follows:

First, the micro course video adopted by flipped classroom should be consistent with the classroom teaching objectives. Teachers should not directly refer to the existing micro course resources, but should master skilled information technology ability to integrate and even make excellent micro courses, so as to better serve the teaching.

Second, the teaching structure and teaching design of flipped classroom are the core of the research. The implementation of flipped classroom requires students to complete self-study before class, and it is particularly critical for teachers to make full use of information technology to solve the difficulties in students' online independent learning, and to effectively track students' learning situation( Blair et al., 2016) [30].

Third, flipped classroom requires teachers to have strong classroom organization and time control ability, and effectively carry out classroom communication, discussion and personalized guidance around problems, stimulate students' learning interest, enthusiasm and participation, create a good classroom atmosphere, and cultivate students' independent learning ability, collaborative inquiry ability and creativity.

In short, the flipped classroom requires us to practice and accumulate experience to construct the flipped mode suitable for higher vocational students.

\section{REFERENCES}

[1] N. Milman, "The flipped classroom strategy: What is it and how can it be used?" Distance Learning, vol. 9, no. 3, pp. 85-87, 2012.

[2] J. Bergmann and A. Sams, "Flip your classroom: Reach every student in every class every day," DC International Society for Technology in Education, pp. 21-37, 2012

[3] K. Long, "Washington college instructors are 'flipping' the way they teach[OL], 2013

[4] L. Deslauriers, E. Schelew, and C. Wieman, "Improved learning in a large —enrollment physics class," Science, no. 332, pp. 862-864, 2011

[5] Y. G. Zhang and Y. J. Zhang, "Perspective 'flipped classroom,," Primary and Secondary School Information Technology Education, vol. 3, pp. 9-10, 2012.

[6] J. L. Zhang, Y. Wang, and B. H. Zhang, "Research on flipped classroom teaching model," Journal of Distance Education, vol. 4, pp. 46-51, 2012.

[7] X. L. Zhao, "The advancement and limitation of flipped education," Journal of The Chinese Society of Education, no. 4, pp. 65-68, 2013.
[8] Q. L. Zhang and B. H. Zhang, "Study on the application of gamification learning concept in flipped classroom teaching," Journal of Distance Education, no. 1, pp. 73-78, 2013.

[9] S. S. Shen, Q. Liu, and T. X. Xie, "A flipped classroom teaching model based on electronic backpack," China Educational Technology, no. 12, pp. 107-111, 2013.

[10] Y. Jin, "Practical research on flipped classroom teaching model based on micro-course - A case study of basic computer application course," Vocational \& Technical Education Forum, no. 23, pp. 55-58, 2014.

[11] C. X. Lan, "An empirical study on the course teaching of computer foundation in higher vocational colleges based on flipped classroom," Vocational \& Technical Education Forum, no. 23, 73-77, 2015.

[12] L. Li, "Teaching design and implementation of 'flipped classroom' Taking international marketing courses as an example," Foreign Economic and Trade, no. 11, pp. 143-145, 2015.

[13] (2014). What is Flipped Learning. Flipped Learning Network. [Online]. Available:

http://fln.schoolwires.nedcms/lib07/VA01923112/Centricity/Domain/ 46/FLIP_handout_FNL_Web

[14] P. Schmidt et al., "The flipped classroom: A twist on teaching," Contemporary Issues in Education Research (Online), no. 9, p. 1, 2016.

[15] J. Demski, "6 expert tips for flipping the classroom," Campus Technology, no. 5, pp. 32-37, 2013.

[16] M. Frydenberg, "The flipped classroom: It's got to be done right," 2012.

[17] Q. Zhang and L. Y. Yang, "Innovation practice and empirical research of modern education technology based on FLIPPER flipped teaching model," Information Teaching, no. 17, pp. 110-115, 2016.

[18] V. X. Dai, Y. D. Wang et al., "Study on the influence of flipped teaching cooperative learning on the learning effect of life science and technology practical course," Science Education Journal, no. 24, pp. $57-58,2016$.

[19] A. Raoul, "Flipping a college mathematics classroom: An action research project," Education and Information Technologies, no. 11, pp. 1-14, 2018.

[20] Y. J. Song and K. Manu, "How to flip the classroom - 'Productive failure or traditional flipped classroom' pedagogical design?" Journal of Educational Technology \& Society, no. 20, pp. 292-305, 2017.

[21] M. Kathy et al., "Flipping the classroom to improve student performance and satisfaction," Journal of Nursing Education, no. 10, pp. 597-599, 2013.

[22] N. Hosung et al., "Exploring flipped classroom effects on second language learners' cognitive processing," Foreign Language Annals, no. 2 , pp. $260-284,2017$

[23] A. Gülsüm, "The effects of the gamified flipped classroom environment (GFCE) on students' motivation, learning achievements and perception in a physics course," Quality and Quantity, no. 1, pp. 129-145, 2018.

[24] E. Millard, "5 Reasons Flipped Classrooms Work: Turning lectures into homework to boost student engagement and increase technology fueled creativity," pp. 26-29, 2012.

[25] M.-K. Lee, "Flipped classroom as an alternative future class model?: implications of South Korea's social experiment," Educational Technology, Research and Development, no. 3, pp. 837-857, 2018.

[26] A. J. Boevé et al., "Implementing the flipped classroom: an exploration of study behaviour and student performance," Higher Education, no. 6 , pp. 1015-1032, 2017.

[27] L. Maria et al., "Traditional and flipped classroom approaches delivered by two different teachers: The student perspective," Education and Information Technologies, no. 23, pp. 797-817, 2018.

[28] S. McLean et al., "Flipped classrooms and student learning: Not just surface gains," Advances in Physiology Education, no. 1, p. 47, 2016

[29] C. E. Smith, "The flipped classroom: Benefits of student-led learning," Nursing, no. 4, p. 20, 2017.

[30] B. Erik et al., "Performance and perception in the flipped classroom," Education and Information Technologies, no. 6, pp. 1465-1482, 2016.

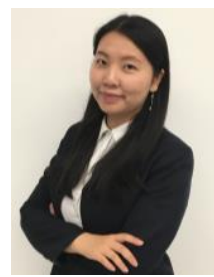

Yanbing Liang was born Nov. 30, 1985 in China. She is a marketing teacher at Guangdong Vocationa College of Posts and Telecom Economic Management Institute. She received the master of management in Guangdong University of Foreign Studies in 2010. She is good at marketing. She joined academia after spending more than 7 years in management at Guangzhou metro group co. LTD of China. 